\title{
Indústria criativa e mercado de trabalho: breves aproximações para a categoria da exploração do trabalho criativo
}

\author{
Thiago Cavalcante de Soura ${ }^{1}$
}

\begin{abstract}
Resumo: No atual estágio do capitalismo contemporâneo, o capital e o trabalho assumiram uma dimensão transnacional, sendo conectados globalmente por redes criativas de informação. Desse modo, a comunicação e a criatividade humana incorporaram um aspecto mercantil, dado que a capacidade de gerar, processar e aplicar a informação e o conhecimento de forma eficiente segmentou um tipo particular de indústria, a criativa e computacional. Em face dessas questões, a demanda por trabalho apresentou importantes transformações, em que se destaca o aumento da procura por mão de obra especializada, além do crescimento da estrutura ocupacional entre os setores econômicos que consideram a criatividade, a tecnologia e a inovação recursos primários. Nessa perspectiva, este artigo investiga de que maneira a relação entre Criatividade e Dependência proposta por Celso Furtado e a teoria da Superexploração da Força de Trabalho de Ruy Mauro Marini demonstram-se capazes de explicar a maneira pela qual o capital expropria-se do trabalho intelectual e cognitivo. Para o exercício realizado, serviu de referência a indústria criativa do Brasil e, para a análise, o instrumento utilizado foi o método dedutivo. O trabalho conclui que a lógica de expropriação do trabalho nessa indústria criativa ultrapassa a dimensão da exploração da força física, estendendo-se para à capacidade intelectual e cognitiva. Essa lógica alude a ideia de superexploração da força de trabalho pelo fato do salário pago aos trabalhadores não se demonstrar suficiente à recomposição do estímulo criativo. Ademais, o exercício da criatividade não obedece, necessariamente, a uma jornada de trabalho fixa, o que estende a atividade laboral para além, mas sem uma compensação salarial pelo tempo adicional.
\end{abstract}

Palavras-chave: Criatividade. Dependência. Trabalho.

Abstract: At the present stage of contemporary capitalism, capital and labor have taken on a transnational dimension, being globally connected by creative networks of information. In this way, communication and human creativity have incorporated a commercial aspect, since the ability to efficiently generate, process and apply information and knowledge has segmented a particular type of industry, such as creative and computational. In view of these issues, the demand for labor has undergone important changes, in which the demand for skilled labor is increasing, as well as the growth of the occupational structure among the economic sectors that have creativity, technology and innovation as primary resources. In this perspective, this article investigates how the relation between Creativity and Dependence proposed by Celso Furtado and the theory of Superexploration of the Work Force of Ruy Mauro Marini are able to explain the way in which capital expropriates of the intellectual and cognitive work. The exercise uses the Brazilian creative industry as a reference, using the deductive method as an analysis tool. The work concludes that the logic of expropriation of labor in this creative industry goes beyond the dimension of the exploitation of physical force, extending to the intellectual and cognitive capacity. This logic alludes to the idea of overexploitation of the labor force by the fact that the salary paid to the workers does not prove sufficient to the recomposition of the creative stimulus. In addition, the exercise of creativity does not necessarily follow a fixed working day, which extends the work activity beyond, but without a compensation of the additional time.

Keywords: Creativity. Dependency. Job.

\footnotetext{
${ }^{1}$ Doutorando em Economia pelo Programa de Pós-Graduação em Economia (PPGE) do Instituto de Economia e Relações Internacionais da Universidade Federal de Uberlândia (IERI-UFU). Pesquisador do Núcleo de Economia Aplicada da mesma instituição. Bolsista da Coordenação de Aperfeiçoamento do Nível Superior (Capes). E-mail: thiagocs@ufu.br.
}

Página 130 Caderno de Ciências Sociais Aplicadas, Vitória da Conquista/BA, vol. 16, n² 27, ano 16, p. 130-157, jan/jun 2019. 


\section{Introdução}

No atual estágio do capitalismo contemporâneo, o capital e o trabalho assumiram uma dimensão transnacional, sendo conectados globalmente por redes criativas de informação. Desse modo, a comunicação e a criatividade humana incorporaram um aspecto mercantil, dado que a capacidade de gerar, processar e aplicar de forma eficiente a informação e o conhecimento segmentou um tipo particular de indústria: a criativa e computacional. Em face dessas questões, a demanda por trabalho apresentou importantes transformações, em que se destaca o aumento da procura por mão de obra especializada, além do crescimento da estrutura ocupacional entre os setores econômicos para os quais a criatividade, a tecnologia e a inovação constituem recursos primários (CASTELLS, 2000). Nesse sentido, a informação, o conhecimento e a criatividade tornam-se elementos essenciais para a dinâmica do processo de acumulação de capital engendrado, tanto na perspectiva da inovação direcionada ao setor produtivo quanto na codificação de informações para subsidiar decisões de investimento sob a condição de incerteza.

É nesse contexto de transformações do modo de produção capitalista contemporâneo que surgem denominações setoriais, a exemplo da indústria criativa. A indústria criativa consiste em um complexo produtivo que ultrapassa a produção fabril e abarca um expressivo conjunto de setores econômicos que dependem do talento e da criatividade humana para se desenvolverem, os quais compartilham características comuns. Esses setores transacionam mercadorias (produtos e serviços) dotados de significados e elementos de precificação subjetiva e intangível, como originalidade e sofisticação tecnológica. Por isso, uma obra de arte consiste em uma mercadoria criativa, tanto quanto um serviço de streaming de conteúdo audiovisual, pois é a criatividade revelada na originalidade, na codificação de informações e signos sociais, na estética e na tecnologia (clássica ou contemporânea) que motiva as relações mercantis e configura a formação monetária.

$\mathrm{Na}$ literatura vinculada às Ciências Sociais Aplicadas, a indústria criativa vem sendo considerada uma alternativa relevante de inserção produtiva (COUTINHO, 2012; OLIVEIRA et al., 2013; MACHADO et al., 2013; SOUZA, et al., 2015), visto que, com recursos intangíveis e provenientes da própria capacidade criativa, possibilita aos indivíduos produzir mercadorias que incorporem signos sociais e culturais para comercializarem, por vezes, de forma coletiva (associações e cooperativas) e em mercados alternativos, como feiras de artesanato, plataformas de apresentações culturais, núcleos comerciais de regiões turísticas, etc. Outra direção da literatura especializada aponta para a massificação

Página 131 Caderno de Ciências Sociais Aplicadas, Vitória da Conquista/BA, vol. 16, n 27, ano 16, p. 130-157, jan/jun 2019. 
e reprodução global da criatividade humana, que torna, por exemplo, a arte e a cultura mercadorias descontextualizadas de seus símbolos e signos sociais, com o intuito meramente mercantil. Nessa vertente da indústria criativa imperam os ganhos por meio da propriedade intelectual representada pelos setores que realizam a convergência das atividades de comunicação, mídia, informação, cultura e artes (JEFFCUTT; PRATT, 2002) e setores de base científica e tecnológica, com alto grau de apropriabilidade - direitos autorais, patentes, segredos industriais, marcas e conteúdo simbólico e outros ativos intelectuais protegidos (BOCCARDELLI, 2016).

Percebe-se, assim, que a indústria criativa ultrapassa os limites da produção artístico-cultural música, dança, teatro, cinema, pintura e literatura - e desdobra-se em atividades econômicas relacionadas com mídias digitais, publicidade e propaganda, computação, conteúdo, arquitetura, nanotecnologia, biotecnologia e os atividades industriais portadoras de futuro, a exemplo das indústrias de inteligência artificial, de automação, robótica, big data. Estima-se que no Brasil, essas atividades econômicas representem 2,64\% do Produto Interno Bruto (PIB), movimentando cerca de R\$155,6 bilhões em mercadorias em 2015, segundo a Federação das Indústrias do Rio de Janeiro (FIRJAN, 2016). Dados do Ministério do Trabalho e Emprego (MTE) inseridos no Mapeamento da Indústria Criativa no Brasil, publicado pela FIRJAN, identificam que esse conjunto setorial é responsável por 851,2 mil empregos, o que representa 1,8\% do total de trabalhadores com registros formais no Brasil, em 2015. Nesse sentido, emergem no debate teórico, sobretudo aquele ligado à estrutura de classes, questões importantes sobre os efeitos da indústria criativa sobre a organização e a natureza do trabalho. Ainda que a participação relativa dessa indústria na estrutura ocupacional seja pequena, sua dinâmica supera setores tradicionais da economia brasileira e possui características distintivas de flexibilidade.

Em face desses aspectos, o presente artigo pretende contribuir com a discussão reportada na presente introdução ao questionar se a dinâmica da indústria criativa brasileira apresenta traços de superexploração na organização e natureza do trabalho alocado em setores criativos. Esse questionamento está teoricamente fomentado pela perspectiva de criatividade e subdesenvolvimento presentes em Furtado (1978) e Marini (1973). Por isso, o objeto central do trabalho reside na hipótese de que, nessa indústria, o capital se expropria do arcabouço cognitivo dos trabalhadores como mecanismo de geração de rendimentos adicionais. Para deduzir metodologicamente essa hipótese, o artigo desenha os seguintes objetivos: a) apresentar os elementos teórico-constitutivos do processo de trabalho no contexto de mudança técnica e formação de expectativa que marcam o capitalismo; b) relacionar a criatividade humana a categoria da dependência econômica no contexto da civilização (pós)

Página 132 Caderno de Ciências Sociais Aplicadas, Vitória da Conquista/BA, vol. 16, n 27, ano 16, p. 130-157, jan/jun 2019. 
industrial; c) submeter os indicadores do Mapeamento da Indústria Criativa do Brasil ao argumento da superexploração.

$\mathrm{O}$ artigo estrutura-se em cinco seções, incluindo esta introdução. $\mathrm{Na}$ segunda seção, apresentam-se os procedimentos teórico-metodológicos da pesquisa. Sequencialmente, na terceira seção, fundamentam-se os elementos teórico-constitutivos do processo de trabalho no contexto de mudança técnica e formação de expectativa que marcam o capitalismo em Marx. Posteriormente, a quarta seção relaciona a criatividade humana a categoria da dependência econômica no contexto da civilização (pós) industrial com base em Furtado e Marini. A quinta seção apresenta a conjuntura do mercado de trabalho criativo no Brasil, cujos dados são interpretados com fundamento no referencial teórico-analítico selecionado nas seções anteriores. Finalmente, a sexta seção esboça as considerações finais e sintetiza os argumentos do artigo.

\section{Metodologia}

Definidos os objetivos e a situação-problema, o presente estudo adotará o método de abordagem hipotético-dedutivo que, segundo Lakatos e Marconi (1991, p.72), "defende o aparecimento, em primeiro lugar, do problema e da conjectura, que serão testados pela observação e experimentação". Portanto, a pesquisa buscará falsear os enunciados hipotéticos formulados com base na questão problema, no seu aspecto teórico e factual. Desse modo, recorre-se a métodos de inferência teórica, os quais buscam subsidiar argumentos de caráter não probabilístico sobre a verdade das predições formuladas. Em um sentido popperiano, o proposito do método empregado nessa pesquisa é expor o argumento de que o trabalho criativo é autônomo e independente do capital à crítica. Ademais, busca-se falsear a categoria da "exploração do trabalho" como instrumento suficiente de crítica.

De acordo com Simske (1979), o método hipotético-dedutivo consiste em um artifício metodológico de abordagem teórica, cuja análise do objeto de investigação problematizado ocorre por meio de elementos heurísticos. Empregam-se, desse modo, narrativas e interpelações teóricas circunstanciadas e referenciadas, uma estratégia para sintetizar a análise. Segundo Vaz (1998), o conjunto de estratégias analíticas do método expressa-se em uma rotina científica que perpassa: a) definição do questionamento central da pesquisa; b) revisão dos elementos teóricos constitutivos da análise do objeto de investigação; c) estrutura teórica de investigação das categorias teórico-analíticas ou variáveis de estudo; d) formulação das hipóteses; e) desenho da investigação mediante o analytical corpus;

Página 133 Caderno de Ciências Sociais Aplicadas, Vitória da Conquista/BA, vol. 16, n 27, ano 16, p. 130-157, jan/jun 2019. 
e) interpretação, que consiste na submissão do analytical corpus ao referencial teórico analítico rebuscado; e, finalmente f) conclusões gerais.

Nesta pesquisa, o emprego do método não almeja determinismo, causalidade e predição. Seria incoerente essa expectativa, dada a própria natureza do amparo teórico de fundamentação. O uso do método hipotético-dedutivo é legítimo para essa investigação unicamente por permitir uma dedução heurística da relação de convergência entre o fato, a teoria e o questionamento central, utilizando-se de uma dimensão epistemológica para se atingir essa finalidade analítica. Para isso, quanto à tipologia do procedimento, far-se-á uso da dialética e da desconstrução, de modo que as inferências não probabilísticas sejam submetidas à justificação, admitindo, desse modo, a ideia de que o exercício metodológico busca aproximar a categoria da superexploração ao objeto.

A hermenêutica dessa aproximação será baseada no Mapeamento da Indústria Criativa do Brasil (FIRJAN, 2016). Tal documento concentra sua comparação descritiva nos anos de 2013 e 2015, motivo pelo qual a análise não será estendida para um período temporal mais amplo. A proposta dialética é contrastar os argumentos em torno da dinâmica do mercado de trabalho criativo com a categoria analítica da superexploração. A interpretação furtadiana de criatividade servirá de suporte para se discutir os modelos teóricos de classificação setorial da indústria criativa, de modo a verificar se tais modelos aludem a argumentos de superexploração da força de trabalho, de modo que se possa inferir a dedução dessa ocorrência no Brasil.

\section{Capitalismo: processo de trabalho, mudança técnica e formação de expectativa}

De acordo com Marx (2001a, p. 5; [1867]), a riqueza da sociedade capitalista assenta-se na acumulação de um conjunto de mercadorias, no qual se vincula o trabalho. Porquanto, "o valor de uma mercadoria é determinado pela quantidade de trabalho abstrato socialmente necessário para a sua produção". Essa exposição chama-se atenção para o tempo de trabalho executado e exigido para a produção de uma mercadoria, denotando, assim, um grau médio de habilidade e de intensidade requerida para que o trabalho possa conferir valor à mercadoria produzida.

Em uma interpretação desse postulado teórico-conceitual, Carcanholo (2007) sublinha a distinção que a obra de Marx faz em relação à natureza do trabalho - trabalho produtivo e improdutivo. O primeiro produz tanto o valor necessário para reprodução da força de trabalho, como também o excedente captado pelo capitalista no processo de formação do lucro. Nas palavras do

Página 134 Caderno de Ciências Sociais Aplicadas, Vitória da Conquista/BA, vol. 16, n 27, ano 16, p. 130-157, jan/jun 2019. 
próprio Marx (2001b, p. 138; [1867]), o trabalhador produtivo é aquele responsável por produzir maisvalia e autovalorização do capital e exemplifica:

[...] um mestre-escola é um trabalhador produtivo se ele não apenas trabalha as cabeças das crianças, mas extenua a si mesmo para enriquecer o empresário. [...] O conceito de trabalho produtivo, portanto, não encerra de modo algum apenas uma relação entre a atividade e efeito útil, entre trabalhador e produto do trabalho, mas também uma relação de produção especificamente social.

Portanto, o trabalhador é o meio de valorização do capital. Nessa perspectiva, o trabalho produtivo faz-se mediante aptidões físicas e intelectuais:

O trabalho não é senão o uso da força de trabalho, cujo conteúdo consiste nas aptidões físicas e intelectuais do operário. Sendo assim, o salário não paga o valor do trabalho, mas o valor da força de trabalho, cujo uso, no processo produtivo, cria um valor maior do que o contido no salário. O valor de uso da força de trabalho consiste precisamente na capacidade, que lhe é exclusiva, de criar um valor de grandeza superior à sua própria. $\mathrm{O}$ dono do capital e empregador do operário se apropria deste sobrevalor ou mais-valia sem retribuição (MARX; 2001a, p. 37; [1867]).

Interpretando Marx, Herscovici (1996, p. 140) declara que o trabalho se descaracteriza na condição de produtivo "na medida em que ele não é socializado, sob forma mercadoria, por sua validação no mercado", o que não o viabiliza como mecanismo de valorização do capital. Destaca, ainda, que "no que concerne aos serviços, eles não são produtivos apenas quando o trabalho é trocado por renda e não por capital". Porquanto, o trabalho possui uma função social, muito mais do que produtiva, e é, por meio da exploração, o mecanismo elementar do processo de acumulação. Dessa forma, compreende-se que o caráter improdutivo advém da não função social.

Para Marx (2001; [1867]), o trabalho é um processo entre o homem e a natureza, no qual se põem em movimento as forças naturais pertencentes a sua capacidade física relevada na força de seu corpo com a finalidade de apropriar-se da matéria natural em uma forma útil para sua própria vida. Ao atuar, por meio desse movimento, o trabalhador emprega muito mais do que a sua força física, mas aciona a sua capacidade de expropriar-se de sua natureza em razão do objetivo do trabalho. Nesse sentido, os elementos do processo de trabalho são a atividade orientada a um fim revelado pelo trabalho em si, pelo seu objeto e pelos meios de trabalho no qual o indivíduo emprega sua força e intelectualidade, resultando na conformação de mercadorias.

Página 135 Caderno de Ciências Sociais Aplicadas, Vitória da Conquista/BA, vol. 16, n 27, ano 16, p. 130-157, jan/jun 2019. 
Dessa forma, o processo de trabalho extingue-se no produto que se refere a um valor de uso, isto é, uma matéria natural adaptada às necessidades humanas mediante transformação da forma. Marx (2001a, p. 300; [1867]) considera que:

O processo inteiro, do ponto de vista de seu resultado, do produto, aparecem ambos, meio e objeto de trabalho, como meios de produção, e o trabalho mesmo como trabalho produtivo. Quando um valor de uso sai do processo de trabalho como produto, outros valores de uso, produtos de processos anteriores de trabalho, entram nele como meios de produção. $\mathrm{O}$ mesmo valor de uso constitui o produto desse trabalho, e o meio de produção daquele. Produtos são, por isso, não só resultados, mas ao mesmo tempo condições do processo de trabalho.

Não há como negar, desse modo, que as condições do processo de trabalho tornam-se substancialmente modificadas com a modernização do processo produtivo e, não nos referimos ao emprego das forças físicas e intelectuais do trabalhador na conformação do produto capitalista. Referimo-nos à configuração do sistema produtivo, revelado pela modificação dos meios de trabalho, que potencializam o aumento da produtividade do trabalho. Uma inovação no conjunto de capital físico do sistema produtivo não força a intensidade do trabalho de maneira única. É preciso pensar em aparatos organizacionais que tornem o processo de trabalho mais veloz, ágil e aderente à realidade de um sistema produtivo automatização. Isso exige muito mais do trabalhador, pois sua capacidade cognitiva deve ser despertada para oferecer reciprocidade à celeridade do processo de trabalho que um novo equipamento exige do indivíduo.

Isso porque "a tecnologia desvela a atitude ativa do homem em relação à natureza, o processo imediato de produção de sua vida e, com isso, também de suas condições sociais de vida e das concepções espirituais que delas decorrem” (MARX; 2001a, p. 434; [1867]). A tecnologia é, sem dúvida, a forma materializada do processo de trabalho, na qual as forças produtivas e as relações de produção subjacentes são expressas. Assim, conforme sustenta Harvey (2006, p. 183), “cada modo de produção desenvolve um tipo específico de ciência, um 'sistema de conhecimento' apropriado para suas necessidades físicas e sociais distintas". No processo de trabalho, não é apenas a força física que valoriza o capital, mas também as capacidades inventivas do trabalhador, seja para propor inovações, seja no ato de adaptar e, com isso, criar procedimentos e rotinas distintas de uso da máquina. Tal procedimento resulta em atributos da mercadoria que poderão fazer com que o empresário a comercialize por preço superior ao seu valor, sem, contudo, retribuir ao trabalhador tal "oportunidade". Isso reforça a ação de exploração.

Página 136 Caderno de Ciências Sociais Aplicadas, Vitória da Conquista/BA, vol. 16, n 27, ano 16, p. 130-157, jan/jun 2019. 
Ao elencar a relevância da contribuição de Marx para explicar a discrepância entre o ritmo de progresso técnico entre as sociedades, Rosenberg (2006; [1982]) apontou a mudança técnica como motor do processo de acumulação de capital. Na perspectiva do autor, o processo de acumulação de capital definido pelo ritmo do progresso técnico modifica a intensidade do trabalho, o que para nós acelera e expande o processo de exploração do trabalho. Porquanto, os imperativos tecnológicos, dados pela cumulatividade do conhecimento dos trabalhadores contribuem, em grande medida, para a aceleração do progresso técnico.

Isso porque a criatividade e a experiência do trabalhador no processo de trabalho resultam em melhorias que, se incorporadas ao aspecto científico, permitem ao capitalista obter novos mecanismos técnicos de produção. Consequentemente, os conhecimentos tácitos dos trabalhadores incentivam o desenvolvimento de tecnologias que ampliaram a intensidade do trabalho, fazendo com que a captura do excedente do trabalho pelo empresário evolua com o processo "criativo" de trabalho. Ademais, tal conhecimento tácito é responsável por tornar o trabalhador mais hábil no processo de confecção das mercadorias, tornando-o mais especializado no processo de trabalho. Dessa forma, as mercadorias chegaram ao mercado com qualidade superior. É o caso de "roupas de grife", cuja mercadoria incorpora um aspecto de originalidade e de qualidade imposto pela destreza do trabalhador. Com isso, eleva-se o preço da mercadoria, mas mantém-se a remuneração do trabalho constante. Ora, mas é o trabalho o responsável pelo valor de uso da mercadoria, o que ressalta uma das contradições do capitalismo.

$\mathrm{Na}$ perspectiva keynesiana e evolucionária, as novas tecnologias e equipamentos ampliam as receitas de vendas simultaneamente à redução dos custos de produção, modificando a eficiência marginal do capital e, portanto, o grau de investimento. Contudo, o desconhecimento sobre essas inovações poderá afetar o otimismo dos empresários, o que implica diretamente a sua propensão a realizar investimentos. Nesse sentido, compreende-se que a incerteza e o processo de formação de expectativas de investimento podem receber influências expressivas da mudança tecnológica, na medida em que estas sejam capazes de alterar a eficiência marginal do capital.

Dosi, Fagiolo e Roventini (2010) ressaltam que o arcabouço tecnológico das firmas apresenta heterogeneidade, o que conduz a decisões de investimentos diferenciadas. Isso porque o nível de investimento direcionado ao estoque de capital e a mudança tecnológica correspondem a uma estratégia adaptativa, por meio da qual as firmas buscam preservar-se no mercado. Consequentemente, a mudança tecnológica resultante de estratégias adaptativas focadas nos investimentos em estoque de

Página 137 Caderno de Ciências Sociais Aplicadas, Vitória da Conquista/BA, vol. 16, n² 27, ano 16, p. 130-157, jan/jun 2019. 
capital apresenta descontinuidades no tempo, refletindo em instabilidade no sistema econômico, alternando períodos de crise e crescimento (TIGRE, 2014). De acordo com Baptista (1997), a abordagem evolucionária de inspiração schumpeteriana afirma que as estratégias adaptativas impõem às firmas um conjunto de decisões complexas sempre que acionam investimentos orientados à sua capacidade instalada ou a uma nova trajetória tecnológica, de forma que a capacidade criativa dos indivíduos de lidarem com essas decisões é fundamental para o raciocínio lógico-mercadológico do empresário capitalista.

Inerente a esse contexto, Kupfer (1992) assevera que o processo decisório relativo às estratégias adaptativas focadas nos investimentos tecnológicos depende, primordialmente, das expectativas dos empresários quanto ao futuro das inovações e, portanto, ocorre em condições de incerteza. Portanto, quanto maior e mais drástica for a inovação, maior será a incerteza do empresário quanto aos retornos do investimento empregado. Assim, o emprego da criatividade humana com a finalidade de modernizar as forças de produção tornar-se-á tão mais importante quanto a força de trabalho física. Desse modo, a criatividade vinculada ao processo produtivo estará ligada tanto ao seu espectro econômico (ideia cognitivas com finalidade resolutiva de problemas) com o espectro científico (ideias cognitivas formalizadas e codificadas em uma base de conhecimento que proporcione rotinas heurísticas de transformação e resolução problemas), fortemente empregado no capitalismo contemporâneo por meio de laboratórios de P\&D.

Os mercados contemporâneos expõem a criatividade da força de trabalho a mecanismos de seletivos (demanda, legislação, aspectos institucionais e outros), de modo que as mercadorias derivadas da criatividade humana só se consolidarem no mercado depois de superados esses entraves. Por isso, o exercício criativo deve ser constante. Acrescenta-se a esse fato a incerteza sobre o caráter seletivo dos mercados, de modo que uma mercadoria não é consolidada ex-ante. Portanto, o exercício criativo contido em uma inovação, por exemplo, pode tornar-se obsoleto rapidamente, impondo uma redução significativa do valor de troca das mercadorias derivadas de tais mudanças tecnológicas. Com isso, o capitalista tende a destinar maior ênfase ao processo de mudança tecnológica do que à maturação criativa de sua base produtiva assalariada. Dessa forma, o exército de reserva está presente, mas em um grau de percepção acima do que é encontrado entre trabalhadores que são remunerados apenas por sua força de trabalho física.

A constante troca de postos de trabalho no mercado de trabalho criativo pode ser atrelada a constantes alterações na trajetória tecnológica de uma determinada base produtiva. Ainda em uma

Página 138 Caderno de Ciências Sociais Aplicadas, Vitória da Conquista/BA, vol. 16, n 27, ano 16, p. 130-157, jan/jun 2019. 
perspectiva evolucionária, Dosi (1988, p. 1227, tradução própria) assevera que “o sucesso de mudanças tecnológicas futuras dependem, fundamentalmente, das decisões de investimento assumidas (no presente) por todas as firmas do mercado, visto que essas tendem a não cooperar tecnologicamente". Dessa maneira, a incerteza associada à mudança tecnológica amplia-se à medida que a seleção natural dos mercados conduza as firmas rivais a decisões de investimentos autônomas e assimétricas, de forma que as contratações de trabalhadores criativos passarão a ser consideradas um investimento, cuja literatura neoclássica denominará de capital humano e cognitivo. Ora, dada a trivialidade de se substituir trabalhadores, mudanças na composição "dessa forma de capital" serão mais fáceis do que a substituição de bens de capital, de maneira que seguir uma nova trajetória tecnológica e alterar a base de conhecimento (dado pelo pessoal ocupado) tornar-se-á mais hostil, com vistas à sustentação dos interesses capitalistas.

Essa literatura, contudo, permite a compreensão de um atenuante, visto que se considerado o trabalho criativo um motor para a formação de conhecimento tácito, elemento relevante para a dinâmica da mudança tecnológica, mudanças no exército de trabalho nem sempre serão desejáveis ao capitalista, pois existe um esforço de aprendizagem que diminuirá a produtividade do trabalhador criativo. Porquanto, a criatividade é aguçada de forma tácita e temporal. Desse modo, o risco de investimento em mudança tecnológica impactará o mercado de trabalho de acordo com a direção das fontes de mudança tecnológica. Segundo Romero (2014), o risco relacionado aos investimentos em mudança tecnológica possui duas fontes distintas, mas complementares. Primeiramente, destaca-se que o investimento em mudança tecnológica não garante que as inovações necessárias para ampliar as vantagens competitivas perante a seleção natural dos mercados sejam efetivamente alcançadas. Ademais, a criação de uma inovação derivada da mudança tecnológica ou a modernização dos bens de capital destinados à produção não garante a realização de lucros extraordinários, uma vez que esses lucros são dependentes do desempenho do produto no mercado, em termos de demanda. Dessa forma, a ausência de um mercado preexistente que seja capaz de orientar a decisão de investimento tecnológico dificulta a previsão acerca da aceitação do produto pelos consumidores. Paralelamente, as expectativas de surgimento de inovações concorrentes potencializam a incerteza dos retornos da mudança tecnológica, tanto em relação aos ganhos monetários quanto aos estratégicos. Esse fato impacta, analogamente, a composição do mercado de trabalho criativo - profissões mais especializadas.

Nessa perspectiva, as firmas não necessariamente inovam, mas apropriam-se da capacidade intelectual de seus trabalhadores com a finalidade de obter excedente econômico. Para isso, os

Página 139 Caderno de Ciências Sociais Aplicadas, Vitória da Conquista/BA, vol. 16, n 27, ano 16, p. 130-157, jan/jun 2019. 
capitalistas procuram formar uma base de trabalho que permite acumular informações e conhecimentos, em parte, internos à própria firma e, noutra parte, no próprio mercado em que se insere (MACULAN, 2005). A ideia de acumulação de conhecimento (considerando o fenômeno da acumulação peculiar ao capitalismo) já alude para a desigualdade existente no processo de mudança tecnológica em que o trabalho criativo é mobilizado. A literatura evolucionária chama atenção para esses elementos em outra perspectiva, quando trata do processo de aprendizagem. Esse processo é a maneira como os trabalhadores desenvolvem rotinas com base em informações de conhecimentos endógenos e exógenos às firmas. Ou seja, desenvolvem de forma criativa alternativas de produção.

O empresário capitalista baseia suas expectativas de retorno sobre os investimentos em mudança tecnológica fundamentado no processo de reprodução e experimentação criativa que os trabalhadores realizam constantemente, ao ponto que o estoque de aprendizagem aumentará a produtividade, pois permitirá que a tarefas produtivas sejam efetuadas de forma mais rápida e eficiente. Esse estoque é relevante para minimizar as incertezas sobre o investimento. Portanto, a criatividade empregada no processo produtivo é apropriada como mecanismo de decisão por parte do capitalista, mas não é remunerada ao trabalhador. De certo modo, o trabalho criativo que auxilia na diminuição das incertezas dos investimentos mobilizado pelo capitalista é contido nas mercadorias, mas existe aí mais uma apropriação não usual do trabalho.

Esses elementos teóricos reforçam a categoria analítica marxista, uma vez que o empresário, além de utilizar a exploração da força de trabalho como mecanismo orgânico de acumulação de capital, também a utiliza como mecanismo instintivo de determinação do investimento. Portanto, são o conhecimento, o nível de aprendizado e a criatividade dos indivíduos que, capturados mediante rotinas especializadas, corroboram para o surgimento de tecnologias e equipamentos de produção - resultando em maior intensidade no emprego da força de trabalho - além de impor-se tal qual um mecanismo que orienta a acumulação, dado que baliza as decisões de investir do capitalista. Ora, em uma economia financeirizada, será o próprio conhecimento extraído da força de trabalho dos indivíduos que determinará se o lucro advindo da produção será mais propício à acumulação de capital do que a transformação do "dinheiro em dinheiro" (D $\rightarrow$ D') pelas vias financeiras do capitalismo espúrio, balizado na taxa de juros. Aspectos teóricos semelhantes que permitem a sustentação desse argumento estão implícitos na exposição de Rosenberg (2006; [1982]) e Kalecki (1983; [1954]), mas não serão explorados aqui. Ademais, essa compreensão está, de certo modo, subsidiada na obra de Celso Furtado, Criatividade e Dependência na Civilização Industrial.

Página 140 Caderno de Ciências Sociais Aplicadas, Vitória da Conquista/BA, vol. 16, n 27, ano 16, p. 130-157, jan/jun 2019. 


\section{Criatividade, dependência e (super) exploração da força de trabalho}

Segundo Furtado (1978, p. 74), no capitalismo industrial “as energias criadoras puderam ser progressivamente canalizadas e postas a serviço das forças produtivas”, o que inclui a criatividade cultural, científica e tecnológica - objetos da construção social dos indivíduos, os quais o capitalismo procura subordinar aos seus interesses de acumulação e reprodução orgânica e progressiva. Isso porque, segundo o autor, a Revolução Burguesa incitou uma mudança social que centrou a racionalidade do processo produtivo, de modo que a atividade criadoura própria do homem se subverteu aos interesses da acumulação capitalista. Isso posto, advoga que a própria criatividade científica se tornou instrumento de ampliação da eficiência do trabalho, e, consequentemente, de sua produtividade. Desse posicionamento deduz-se que a criatividade científica, subvertida aos interesses do capital, potencializa a exploração do trabalho.

Furtado (1978) trata a criatividade humana em uma perspectiva tridimensional. Na base da vida cotidiana dos indivíduos está a criatividade cultural e econômica. Por um lado, a imaginação e a capacidade de gerar ideias originais proporcionam aos indivíduos novas maneiras de interpretar o mundo. Para tanto, abarcam diversos aspectos da universalidade humana desde o conhecimento, as tradições, a moral, as inferências éticas formais e informais e a arte expressa em texto, som e imagem (CUCHE, 2002), até a identidade intelectual proporcionada pelo tempo e pelo espaço (ELIAS, 1991; HALL, 2001). Por outro lado, a criatividade humana é interpretada como a "faculdade do homem para inovar" (FURTADO; 1978, p. 83), revelada pela capacidade de criar processos que lhes concedem mecanismos de organização da sociedade e de suas formas de produção. Nessa perspectiva, a criatividade científica e a tecnológica tornam-se um produto da sistematização criativa natural do homem, em que a curiosidade, a imaginação e o conhecimento experimentam possibilidades e indicam soluções para os problemas, os conflitos e as necessidades existentes no sistema socioeconômico. Não obstante a interpretação tridimensional (criatividade cultural, científica e técnico-econômica), ressalta "não haver dúvida que nos últimos dois séculos a criatividade humana tem sido principalmente canalizada para a inovação técnica", no campo econômico (idem; p. 44).

Sawaya (2008) interpretando livremente Celso Furtado, afirma:

Página 141 Caderno de Ciências Sociais Aplicadas, Vitória da Conquista/BA, vol. 16, n² 27, ano 16, p. 130-157, jan/jun 2019. 
A “civilização industrial" é o resultado de uma transformação social que subordina a força física e a capacidade intelectual, criativa, à lógica da acumulação de riqueza. Está relacionada a uma estrutura de poder ligada à ideologia da acumulação, à racionalidade instrumental para a organização da produção que condiciona o desenvolvimento das forças produtivas e a própria sociedade. Assim, acumulação, criatividade, técnica, cultura e padrão de consumo constituem-se em um mecanismo lógico fundador da organização social criada pela civilização burguesa [...] (SAWAYA, 2008, p. 329).

Precisamente, Furtado (1978, p. 64) assevera que "nas sociedades surgidas do capitalismo industrial, existe uma relação estrutural entre o grau de acumulação alcançado, o grau de sofisticação das técnicas produtivas e o nível de diversificação dos padrões de consumo". Na égide dessa compreensão, o autor traça uma nova interpretação quanto à natureza do processo de dependência latino-americano, pautado na natureza do padrão de consumo dessas economias e nas diferenças significativas do condicionamento da criatividade científica ao setor produtivo, resultando em expropriação da criatividade cultural das economias periféricas. Esse processo de subordinação revelase na chamada ordem econômica internacional, que se pauta no controle da tecnologia e das finanças e, evidentemente, do próprio mercado. Consequência direta dessa ação, impera o domínio centralizado das fontes de recursos não renováveis e da mão de obra. Portanto, a criatividade fornece um domínio hegemônico às nações que protagonizam o progresso técnico, o que torna a estrutura social e produtiva das economias periféricas subserviente aos interesses do que denominou "a grande empresa", a qual detém o poder econômico e orienta a criatividade para a modernização, transformando-a em tecnologia com fins de acumulação capital.

No âmbito da dependência, Marini (2000; [1973], p. 16) destaca que “a América Latina é levada a reproduzir em seu seio as relações de produção que se encontravam na origem da formação desse mercado [mundial], e determinavam seu caráter e sua expansão". Nesse sentido, adverte:

A circulação se separa da produção e se efetua basicamente no âmbito do mercado externo, o consumo individual do trabalhador não interfere na realização do produto, ainda que determine a taxa de mais-valia. Em consequência, a tendência natural do sistema será a de explorar ao máximo a força de trabalho do operário, sem se preocupar em criar as condições para que este a reponha, sempre e quando seja possível substituí-lo pela incorporação de novos braços ao processo produtivo (MARINI, 2000; [1973], p. 16).

Nessas condições, a força de trabalho se submete à exploração capitalista nas determinações específicas desta, sob as quais se acentua sua tendência negativamente determinada, que atua de modo sistemático e estrutural sob as economias dependentes. Ocorre também o desgaste prematuro da força

Página 142 Caderno de Ciências Sociais Aplicadas, Vitória da Conquista/BA, vol. 16, n 27, ano 16, p. 130-157, jan/jun 2019. 
de trabalho e/ou a reposição de seu desgaste de tal maneira que a substância viva do valor não é restaurada em condições normais (isto é, nas condições sociais dadas), ocorrendo o rebaixamento do seu valor (LUCE, 2018, p. 155).

Em uma tentativa de relacionar as proposições de Celso Furtado às de Ruy Mauro Marine, de forma simplista, sintética e despretensiosa, conclui-se que o processo de subversão da criatividade modifica substancialmente as relações comerciais entre as economias centrais e periféricas, com modificação do padrão de consumo dos trabalhadores das economias dependentes, e a subordinação dos recursos endógenos ao núcleo central, de modo que a única maneira para a reprodução orgânica do capital na periferia seja por meio da superexploração do trabalho. Portanto, quanto mais retrógrado e lento for o progresso técnico de uma economia, maior será o grau de exploração da força de trabalho, sob o reforço da proposição de Marini (2000; [1973]).

Carcanholo (2005 e 2013) declara que essa relação de dependência é evidenciada por uma expressiva transferência do valor produzido na periferia para o núcleo central da economia mundial, via mercado externo. Desse modo, a dinâmica de acumulação de capital das economias centrais ocorre na expropriação centro-periferia, enquanto a dinâmica capitalista dos países periféricos é viabilizada pela superexploração da força de trabalho. Com essa dinâmica de acumulação de capital, o capitalismo dependente pode crescer, contornando sua restrição externa, mas mantendo-se subserviente ao núcleo da economia mundial, moldado pelo progresso técnico.

Segundo Nascimento, Dillenburg e Sobral (2013), as desigualdades engendradas na relação centro-periferia se manifestam mediante remuneração dos trabalhadores abaixo do valor da sua força de trabalho, uma forma de os capitalistas latino-americanos preservarem certo nível de lucratividade, elevando o grau de exploração da força de trabalho latino-americana. Partindo de intepretação análoga, Luce (2018) aponta ao menos quatro formas distintas de superexploração da força de trabalho nas economias latino-americanas: a) pagamento da força de trabalho abaixo do seu valor; b) prolongamento da jornada de trabalho além dos limites normais; c) aumento da intensidade do trabalho além da normalidade; e, d) hiato entre o pagamento da força de trabalho e o elemento central histórico-moral do valor do trabalho.

Página 143 Caderno de Ciências Sociais Aplicadas, Vitória da Conquista/BA, vol. 16, n 27, ano 16, p. 130-157, jan/jun 2019. 


\section{Mercado de trabalho criativo: evidências empíricas e aproximações teóricas para superexploração}

A criatividade é uma capacidade intrínseca às habilidades cognitivas dos indivíduos. Independe de características físicas, culturais, econômicas e sociais. Contudo, revela-se em maior proeminência quando associada ao conhecimento e a aprendizagem, em sua forma codificada ou tácita, pois estes atuam como estimulante do processo de criação cognitiva. Na literatura econômica, a criatividade humana entrelaça-se a diversos conceitos e abordagens teórica: racionalidade restrita, inovação, capital humano e ativos cognitivos.

A necessidade de gerar contínuo excedente econômico impõe-se como um desafio à criatividade humana, o que exige a incorporação constante de inovações ao setor produtivo com a finalidade de elevar os rendimentos do capital. No contexto de dependência econômica - característica da civilização industrial - as distintas necessidades individuais representam estímulos consistentes à criatividade, o que tende a corroborar o pensamento científico, comportamento inovador e a expressão cultural, os quais formam setores segmentados e relevantes.

A literatura econômica tem-se dedicado ao estudo da criatividade, ainda que de forma pontual e associada a outros fatos estilizados. Em Furtado (1978), a criatividade e a inventividade humana vão além do campo ideológico e atingem as diversas categorias de decisão da sociedade, incorrendo em múltiplas perspectivas de interpretações e significados. Na base da vida cotidiana dos indivíduos está a criatividade cultural, em que a imaginação e a capacidade de gerar ideias originais sugerem-lhes novas maneiras de interpretar o mundo. É a criatividade científica. Por meio de inovações e estratégias, testam possibilidades capazes de solucionar problemas existentes no sistema econômico. É a criatividade econômica e tecnológica, uma importante aliada do progresso humano, tecnológico, científico e, sem dúvida, econômico e social.

Em particular, o estudo do mercado de trabalho criativo, enquanto objeto formal, é relativamente recente. As primeiras discussões sobre indústria criativa foram protagonizadas pelo governo australiano e estendida à Grã-Bretanha que, por meio do Departamento de Cultura, Mídia e Esporte (DCMS), envidou os primeiros esforços sistemáticos para classificar a criatividade e a cultura em um conjunto setorial de atividades econômicas, cuja referência é "a sua origem da criatividade individual, habilidade e talento humano para produzir produtos ou ofertar serviços, as quais dispõem de potencial para a geração de riqueza e emprego através da propriedade intelectual” (DCMS, 2011, p. 6, tradução nossa).

Página 144 Caderno de Ciências Sociais Aplicadas, Vitória da Conquista/BA, vol. 16, n² 27, ano 16, p. 130-157, jan/jun 2019. 
Blythe (2001) destaca o esforço de mensuração dos fluxos econômicos existentes nos mercados criativos da economia da Grã-Bretanha, com o objetivo de identificar a capacidade desses mercados em gerar ativos monetários, propondo, para tanto, uma sistematização setorial. Izerrougene, Coelho e Mata (2012, p. 666) apontam o estudo da configuração da estrutura ocupacional do conjunto de atividades econômicas da criatividade, que problematiza a dinâmica das ocupações de base intelectual e de cunho artístico em áreas urbanas. Sobre essa demarcação setorial, os autores ressaltam que a definição se pauta, essencialmente, na "energia intelectual, cuja fonte deriva do patrimônio cultural e natural, e cuja dinâmica está no capital humano, isto é, nas aptidões educacionais e informacionais do fator trabalho".

Florida (2002) indica que a força de trabalho empregada em mercados culturais e tecnológicos configura uma classe criativa de profissionais altamente dependentes de qualificação ou de habilidades artísticas. Souza, Benavides e Pires (2015) analisaram a indústria criativa enquanto estratégia de desenvolvimento regional, sob a ótica das teorias da aglomeração produtiva, considerando os efeitos de arrasto e propulsão. Os resultados apontaram para um padrão espacial heterogêneo decorrente de clusters de especialização do emprego criativo nos estados da região Nordeste do Brasil, os quais apresentam flutuação e dinâmica mais acentuada.

Machado et al. (2013) apontaram a relação existente entre amenidades urbanas e o desenvolvimento de clusters criativos no Brasil. Os autores descrevem o potencial criativo dos territórios brasileiros e incluem as vantagens comparativas em termos de criatividade. $\mathrm{O}$ trabalho identificou aglomerações em cidades de grande relevância para a economia brasileira, como Rio de Janeiro e São Paulo, além de redes urbanas com ocorrência de polos industriais, universidades e/ou centros de pesquisa. Também se verificou que redes urbanas com um histórico cultural marcante tendem a formar clusters criativos voltados para a arte e para a cultura.

Ritsilã e Haapanem (2003) constataram que a mobilidade de trabalhadores criativos ocorre, predominantemente, em redes urbanas densamente povoadas e que dispõem de condições satisfatórias para a inserção no mercado de trabalho. Também se verificou a relevância do acesso à formação educacional para a localização da força de trabalho.

Jacobs (2001) afirma que os sistemas urbanos com maior densidade de profissionais criativos detêm padrão de crescimento mais eficaz, o que estimula a inovação. Nessa perspectiva, Kelly e O’Hagan (2007) utilizam o conceito de externalidades marshallianas para explicar a tendência à concentração dos trabalhadores criativos em determinadas regiões, nas quais às sinergias e os efeitos de

Página 145 Caderno de Ciências Sociais Aplicadas, Vitória da Conquista/BA, vol. 16, n² 27, ano 16, p. 130-157, jan/jun 2019. 
transbordamento intraclasse (arrasto e propulsão) ocorreriam mais intensamente, privilegiando o desenvolvimento regional e setorial da criatividade.

Segundo Souza (2015), esses efeitos de transbordamento não ocorreriam exclusivamente sobre a mobilidade da mão de obra, mas também na alocação espacial de recursos empresariais, especialmente, em atividades econômicas e empreendimentos criativos com bens e serviços de alto valor agregado, como a indústria de tecnologia, entretenimento digital, software e biotecnologia. Esses empreendimentos tendem a se concentrar em torno de regiões que dispõem de arranjos tácitoinstitucionais que forneçam vantagens às suas operações, como os polos de ciência e tecnologia. Os trabalhadores criativos, com alto nível de formação e especialização técnico, geralmente inserido em atividades criativas de alto valor agregado, porém, não atrelam suas decisões locacionais exclusivamente a disponibilidade de oportunidades de emprego.

Esse perfil de trabalhadores costuma ofertar a sua força de trabalho a níveis de remuneração superiores à média geral do mercado de trabalho, destaca Reis (2011). O estudo realizado por Golgher (2008) mostrou que os trabalhadores atrelam suas decisões locacionais aos seguintes fatores de oferta da força de trabalho: condições climáticas, moradia, lazer e a mínima ocorrência de externalidades negativas (poluição, violência e congestionamento de trânsito). Isso porque tais trabalhadores apresentam um nível de remuneração mais elevado do que a média setorial e necessitam de estímulos de bem-estar social e cultural para o exercício da criatividade.

Essas evidências teóricas indicam contornos particulares de configuração do mercado de trabalho criativo. Não obstante, a literatura apresenta-se incipiente quanto a estudos que se propõem analisar as relações e os conflitos relativos à apropriação da força de trabalho criativa em seus diferentes setores. Desconhecem-se, ademais, trabalhos que procuraram incorporar a categoria analítica da superexploração do trabalho à ideia de esfoliação da cognição dos trabalhadores no processo de mercantilização da criatividade humana próprio da indústria criativa. Contudo, essas evidências empíricas parecem interessantes ao propósito de se realizar aproximações teóricas da categoria da superexploração ao mercado de trabalho criativo. Para esse exercício, cabe ressaltar que os trabalhos elencados apresentam diferentes parâmetros para classificar o que são atividades criativas e quais profissões são consideradas trabalho criativo.

Delimitar a classificação setorial da indústria criativa não é uma tarefa trivial, pois existem inúmeras proposições conceituais a respeito de indústria criativa, o que reflete na ausência de um parâmetro universal para classificar as atividades econômicas que lhe são próprias. Nesse sentido, como

Página 146 Caderno de Ciências Sociais Aplicadas, Vitória da Conquista/BA, vol. 16, n 27, ano 16, p. 130-157, jan/jun 2019. 
referência, essa pesquisa considera os modelos analíticos de distribuição nuclear, que tratam a indústria criativa da mesma maneira que uma cadeia produtiva envolvendo setores de naturezas distintas. Esses setores se articulam com símbolos culturais, tecnológicos e midiáticos, cuja composição criativa é mais intensiva no início (núcleo) da cadeia (Quadro 1).

Quadro 1: Modelos analíticos desenhados para analisar a economia criativa

\begin{tabular}{|c|c|c|}
\hline $\begin{array}{c}\text { Modelo } \\
\text { Analítico }\end{array}$ & Referência & Eixo de análise e ideia-força \\
\hline $\begin{array}{l}\text { Modelo } \\
\text { britânico de } \\
\text { Indústrias } \\
\text { Criativas }\end{array}$ & $\begin{array}{l}\text { United Kingdom } \\
\text { Department for } \\
\text { Culture, Media and } \\
\text { Sport } \\
\text { (UK/DCMS, } \\
\text { 2001) }\end{array}$ & $\begin{array}{l}\text { Nesse modelo, as indústrias criativas são aquelas que } \\
\text { requerem habilidade, criatividade e talento, com potencial } \\
\text { de riqueza e a criação de emprego por meio da exploração } \\
\text { de sua Propriedade Intelectual (PI). }\end{array}$ \\
\hline $\begin{array}{l}\text { Propriedade } \\
\text { Intelectual }\end{array}$ & $\begin{array}{l}\text { World Intellectual } \\
\text { Property } \\
\text { Indicators (WIPO, } \\
\text { 2003) }\end{array}$ & $\begin{array}{l}\text { Esse modelo baseia-se em indústrias envolvidas direta ou } \\
\text { indiretamente na criação, fabricação, produção, } \\
\text { transmissão e distribuição de obras protegidas por } \\
\text { direitos. É feita uma distinção entre as indústrias que de } \\
\text { fato produzem a PI e aquelas que são necessárias para } \\
\text { transportar as mercadorias protegidos pela PI ao } \\
\text { consumidor, como as empresas de registro de patentes, } \\
\text { por exemplo. }\end{array}$ \\
\hline $\begin{array}{l}\text { Indústrias } \\
\text { Criativas }\end{array}$ & $\begin{array}{l}\text { United Nations } \\
\text { Conference on } \\
\text { Trade and } \\
\text { Development } \\
\text { (UNCTAD, 2010) }\end{array}$ & $\begin{array}{l}\text { Nesse modelo, as indústrias criativas se fundamentam no } \\
\text { conceito da criatividade como componente simbólico para } \\
\text { gerar mercadorias, com uma forte dependência de } \\
\text { propriedade intelectual. Há também uma distinção entre } \\
\text { "atividades a montante" - atividades tradicionalmente } \\
\text { culturais, artes cênicas ou artes visuais - e "atividades a } \\
\text { jusante" - muito mais próximo do mercado, como } \\
\text { publicidade ou atividades relacionadas às mídias. }\end{array}$ \\
\hline
\end{tabular}

Fonte: Souza et al. (2015).

O modelo de classificação setorial da indústria criativa proposto pelo DCMS (2001) aplica ênfase no conceito de criatividade cultural, cujos rendimentos do capital advêm da propriedade intelectual. Integram esse modelo de classificação os setores de publicidade, arquitetura, mercado de arte e antiguidades, artesanato, design, moda, filme e vídeo, música, artes cênicas, publicação, software, televisão e rádio, videogames e jogos para computador. Nesse caso, as mercadorias produzidas por essas atividades econômicas incorporam símbolos, signos e representações da criatividade do trabalhador, expressam por meio de som, imagem e texto, os quais reproduzem alguns contextos socioculturais: conhecimento, crenças, arte, moral, costumes, hábitos, imagem, estética, expressões e

Página 147 Caderno de Ciências Sociais Aplicadas, Vitória da Conquista/BA, vol. 16, n 27, ano 16, p. 130-157, jan/jun 2019. 
narrativas da realidade. Essas atividades fomentam não apenas a mercantilização de meras mercadorias, mas do conteúdo criativo da capacidade cognitiva do trabalhador. Um filme comercializado em formato de mídia digital, por exemplo, incorpora, além do trabalho físico contido na cadeia produtiva cinematográfica (pré-produção, produção, pós-produção, distribuição e exibição e comercialização) da mercadoria física (um DVD, por exemplo), o trabalho intelectual que fornece a estética e a simbologia dos personagens, roteiro, fotografia e outros. Ademais, essa estética e simbologia são comercializadas em forma de conteúdo adicionado em outras mercadorias, como, por exemplo, uma peça de vestuário que reproduz um ícone do filme (trecho de um diálogo, personagem, logotipo). O ganho do capitalista ultrapassa a relação de monetarização mercantil e explora rendimentos decorrentes da propriedade intelectual da marca. Contudo, não é do capitalista a autoria da obra, de modo que a detenção desse direito autoral o faz explorar o trabalho para além do limite. Isso porque, supondo um design gráfico ou um publicitário, que teve o seu trabalho criativo empregado na iluminação da fotografia do filme, não tem retorno salarial por meio da comercialização das mercadorias de conteúdo (caso da camiseta). Ora, é possível questionar, mas esse trabalhador não receberá o salário pela sua força de trabalho? Sim, mas com base na consideração do modelo nuclear, a sua criatividade está composta nas mercadorias complementares até o final da cadeia, pois se trata da cumulatividade cultural, princípio responsável por monetizar a mercadoria em série.

O modelo proposto pelo WIPO (2003) apresenta uma ênfase concentrada na criatividade científica, não negligenciando, contudo, a criatividade cultural. A proposta de sistematização setorial da atividade criativa ocorre pela distinção de empresas geradoras de conhecimento (propriedade intelectual) e aquelas responsáveis por comercializar mercadorias protegidas ou mesmo serviços de proteção intelectual. O termo propriedade intelectual contém tanto o conceito de criatividade privada como o de proteção pública para os resultados daquela criatividade, sejam elas provenientes da cultura ou da atividade econômica sistematizada. Em outras palavras, a invenção e a expressão criativa, mais proteção, são iguais à propriedade intelectual (SHERWOOD, 1992, p. 22). Desse modo, o conteúdo imaterial e criativo contido em uma marca, patente, segredo industrial, processo produtivo passa a ser incorporado no processo de precificação monetária da mercadoria. Nesse sentido, o conteúdo intelectual advindo de trabalho útil é submetido à apropriação pelo capitalista, o que amplia a "maisvalia". A questão associada a essa interpretação é que as atividades protegidas por direitos intelectuais são passíveis de apropriação pelo capitalista, sem a devida remuneração do valor trabalho, ainda que abstrato, gerado pelo trabalhador especializado, por exemplo. A ausência de remuneração compatível

Página 148 Caderno de Ciências Sociais Aplicadas, Vitória da Conquista/BA, vol. 16, n 27, ano 16, p. 130-157, jan/jun 2019. 
ou proporcional aos rendimentos da propriedade intelectual dissocia os trabalhadores de seus próprios meios de produção. Esse processo de dissociação é uma das características marcantes do capitalismo, mas vê-se potencializado no contexto da indústria criativa e cultural.

A proposição setorial da UNCTAD (2010), de alguma maneira, torna o conceito de indústria criativa mais genérico, de modo que alude tanto a criatividade cultural quanto científica. A preocupação é, portanto, demonstrar que o trabalho criativo está disponível em todos os setores da atividade econômica do capitalismo contemporâneo. Nessa intepretação, o trabalho abstrato apontado por Marx reveste-se de relevância, mas não sinaliza uma apropriação incomum da força de trabalho, visto que, com contornos bem delineados do exercício da criatividade na atividade laboral, está devidamente explicado pela ideia de trabalho útil. Trata-se, então, da ideia de criatividade necessária ao exercício da força de trabalho, sem maiores complexidades que exijam dispêndio maior das capacidades cognitivas do trabalhador. É nessa perspectiva de classificação setorial, inclusive, que subsidia o trabalho informação e alternativo, como o desempenhado por artistas de rua. Sendo estes detentores da sua força de trabalho e autônomo dos meios de produção artística (sua própria arte), todo o esforço empreendido consiste no trabalho realmente necessário para que uma apresentação realizada.

As principais diferenças desses modelos assentam-se nos seguintes aspectos: origem conceitual de indústrias criativas - ênfase (ou não) na questão cultural; geração de valor pela exploração da propriedade intelectual; divergência no entendimento de criatividade, enquanto recurso produtivo principal. Desse modo, a seleção das atividades econômicas que integram cada modelo analítico é definida por sua natureza conceitual, abrangência setorial e características estruturais consideradas na definição de indústria criativa. No geral, cada modelo analítico fornece um parâmetro de classificação setorial que considera econômica (ou produtiva) desenvolvida e como esta se apropria da criatividade. Baseando-se nesses modelos, a FIRJAN, a FUNDAP, a SEC e a FEE definiram um conjunto setorial para a economia criativa brasileira, sistematizando as atividades segundo critérios de similaridade, com base na Classificação Nacional da Atividade Econômica (CNAE). Esse conjunto produtivo foi organizado em três macrossetores (núcleo, atividades relacionadas e apoio), conforme modelo da Firjan da Figura 1.

Página 149 Caderno de Ciências Sociais Aplicadas, Vitória da Conquista/BA, vol. 16, n 27, ano 16, p. 130-157, jan/jun 2019. 


\section{Cadernos de Ciências SOCIAIS APLICADAS}

Figura 1: Distribuição setorial da economia criativa - Brasil (2012).

\begin{tabular}{|c|}
\hline $\begin{array}{l}\text { Publicidade: atividades de publicidade, marketing. } \\
\text { pesquisa de mercado e organização de evenos. }\end{array}$ \\
\hline $\begin{array}{l}\text { Arquitetura: design e projeto de edificaçōes, } \\
\text { paisagens e ambientes. Planejamento e consenvaçâo. }\end{array}$ \\
\hline Design: design gráfico, multimídia e de móveis. \\
\hline $\begin{array}{l}\text { Moda: desenho de roupas, acessórios calçados e } \\
\text { acessórios; modelistas. }\end{array}$ \\
\hline $\begin{array}{l}\text { Expressōes Culturais: } \\
\text { artesanato; folclore; gastronomia. }\end{array}$ \\
\hline $\begin{array}{l}\text { Patrimônio \& Artes: serviços culturais, museologia, } \\
\text { produçấo cultural, património histórico. }\end{array}$ \\
\hline $\begin{array}{l}\text { Música: gravação, edição e mixagem de som; } \\
\text { criação e interpretação musical. }\end{array}$ \\
\hline $\begin{array}{l}\text { Artes Cênicas: atuação; produção e direção de } \\
\text { espetáculos teatrais e de dança. }\end{array}$ \\
\hline $\begin{array}{l}\text { Editorial: edição de livros, jornais, revistas e } \\
\text { conteúdo digital. }\end{array}$ \\
\hline $\begin{array}{l}\text { Audiovisual: desenvolvimento de conteúdo, } \\
\text { distribuição, programação e transmissão. }\end{array}$ \\
\hline $\begin{array}{l}\text { P\&D: desenvolvimento experimental e pesquisa em } \\
\text { geral, exceto biologia. }\end{array}$ \\
\hline $\begin{array}{l}\text { Biotecnologia: bioengenharia, pesquisa em biologia. } \\
\text { atividades laboratoriais. }\end{array}$ \\
\hline $\begin{array}{l}\text { TIC: desenvolvimento de softwares, sistemas, } \\
\text { consultoria em } \mathrm{Tl} \text { e robótica. }\end{array}$ \\
\hline
\end{tabular}
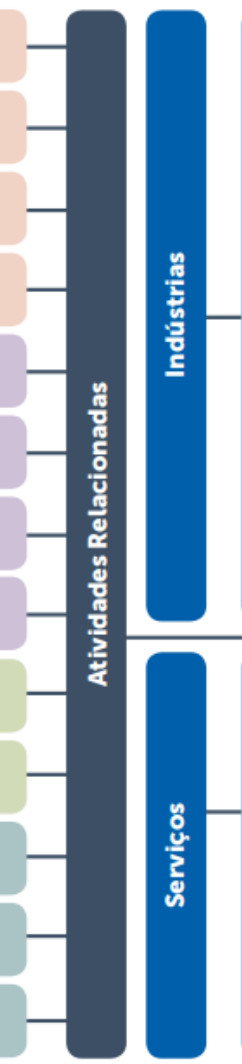

- Materiais para publicidade:

- Confecção de roupas:

- Aparelhos de gravaçăo

e transmissăo de som

imagens:

Impressão de livros, jornais

e revistas:

- Instrumentos musicais

- Metalurgia de metais

preciosos:

- Curtimentos e outras

preparações do cour

- Equipamentos de

nformática;

- Equipamentos

- Cosmética;

- Produção de Hardware:

- Equipamentos de

laboratório:

- Fabricação de madeira e

mobiliário.

Fonte: FIRJAN (2016)

Entre 2004 e 2015, a participação da indústria criativa no Produto Interno Bruto (PIB) do Brasil apresentou crescimento de 0,26\%. Apesar de representar uma magnitude pequena, o percentual supera a participação de outros importantes setores da economia nesse período (LEROY, 2013). Uma questão importante a se considerar é o fato de que mesmo com a desaceleração da economia (2012-2015), a indústria criativa não registra retração na produção. Evidentemente, esse comportamento tende a refletir sobre o comportamento do mercado de trabalho e, sobretudo, na distribuição ocupacional entre as atividades econômicas que o compõem. 


\section{Cadernos de Ciências SOCIAIS APLICADAS}

Figura 2: Estimativa de participação da indústria criativa no PIB do Brasil - 2004-2015.

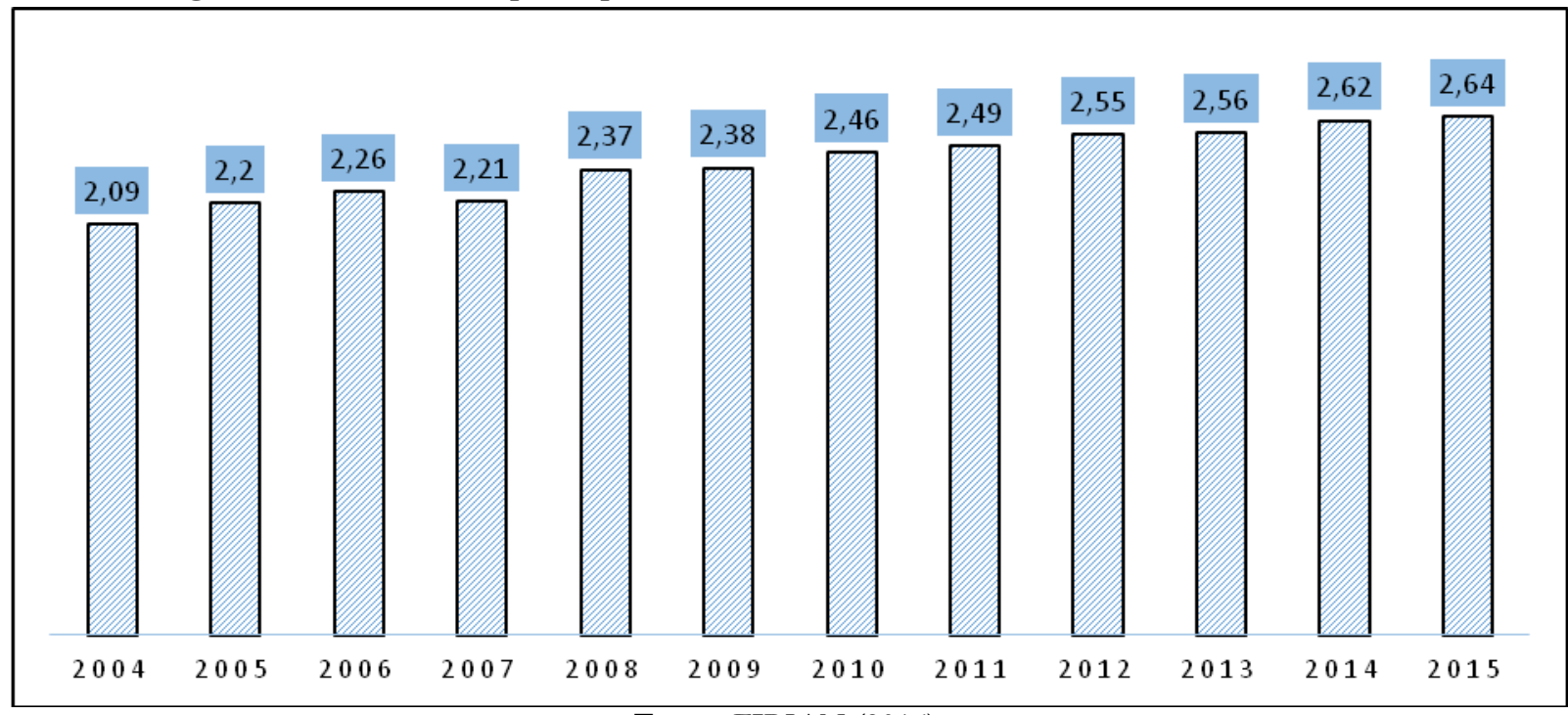

Fonte: FIRJAN (2016).

A Tabela 1 descreve a composição da estrutura do mercado de trabalho formal da indústria criativa nos anos de 2013 e 2015, segundo os setores de atividade que compõem o modelo analítico da FIRJAN (Quadro 1). Os resultados demonstram que, no período analisado, o emprego total registrado na economia brasileira retrocedeu $1,8 \%$, enquanto o da economia criativa praticamente manteve-se estável, registrando variação positiva de $0,1 \%$. Quanto aos salários, quando considerada a média das remunerações referentes aos registros formais para toda a economia, verificou-se uma elevação de 0,4\%. Esse resultado pode ser associado com os ganhos reais de salários que marcam parte do período selecionado. Apesar disso, a média salarial registrada para a indústria criativa decresceu expressivamente, atingindo a redução de 3,4\%, mesmo com a participação dessa indústria demonstrando-se crescente durante todo o período selecionado nessa análise (Figura 2).

É evidente, os dados que se apresentam nessa discussão são limitados, contudo, uma comparação referente à expansão da produção nacional e a redução dos salários, com o nível de emprego formal mantendo-se estável, sinaliza uma evidência empírica da exploração da força de trabalho. Isso porque, uma vez que a produção se expande e o nível de trabalho permanece, a produtividade do trabalho apresenta sinais de elevação. Se considerarmos a discussão relativa ao processo de trabalho em uma economia capitalista formulado por Marx (2001a, [1867]) e a ponderação realizada por Luce (2018), com base em de Marini (2000; [1973]), tem-se que elevar o produto do trabalho sem remunerar o seu devido desgaste consiste em uma expropriação do valor da força de trabalho, nesse caso, revelado pela drástica redução dos salários.

Página 151 Caderno de Ciências Sociais Aplicadas, Vitória da Conquista/BA, vol. 16, n 27, ano 16, p. 130-157, jan/jun 2019. 


\section{Cadernos de CiênCIAS SOCIAIS APLICADAS}

Tabela 1: Pessoal ocupado na indústria criativa, segundo o setor de atividade - 2013/2015.

\begin{tabular}{|c|c|c|c|c|c|c|c|}
\hline \multirow{2}{*}{\multicolumn{2}{|c|}{ Segmento }} & \multicolumn{3}{|c|}{ Empregos } & \multicolumn{3}{|c|}{ Salários } \\
\hline & & 2013 & 2015 & Var. $\%$ & 2013 & 2015 & Var. $\%$ \\
\hline Emprego Tota & & 48.948 .433 & 48.060 .807 & $-1,8$ & $2.442,00$ & $2.451,00$ & $0,40 \%$ \\
\hline Indústria & & & & & & & \\
\hline criativa & & 850.404 & 851.244 & 0,1 & $6.493,00$ & $6.270,00$ & $-3,4$ \\
\hline Consumo & & 380.797 & 376.275 & $-1,2$ & $5.620,00$ & $5.411,00$ & $-3,71$ \\
\hline Publicidade & & 112.667 & 131.717 & 16,9 & 638,00 & $6.276,00$ & $-5,4$ \\
\hline Arquitetura & & 124.470 & 113.499 & $-8,8$ & $8.157,00$ & $7.736,00$ & $-5,2$ \\
\hline Design & & 86.984 & 81.863 & $-5,6$ & $1.663,00$ & $1.724,00$ & 3,7 \\
\hline Moda & & 56.676 & 49.196 & $-13,2$ & $1.663,00$ & $1.724,00$ & 3,7 \\
\hline Cultura & & 62.115 & 66.527 & 7,1 & $2.976,00$ & $2.898,00$ & $-2,6$ \\
\hline Expressões & & 22491 & 26815 & 192 & 177600 & 1852.00 & 43 \\
\hline Culturais & & & & & $1.170,00$ & & $4, J$ \\
\hline Patrimônio & e & & & & & & \\
\hline artes & & 16.423 & 16.005 & $-2,5$ & $4.381,00$ & $4.383,00$ & 0 \\
\hline Música & & 12.022 & 11.989 & $-0,3$ & $2.609,00$ & $2.860,00$ & 9,6 \\
\hline Artes cênicas & & 11.179 & 11.718 & 4,8 & $3.717,00$ & $3.304,00$ & $-11,1$ \\
\hline Mídias & & 101.388 & 95.099 & $-6,2$ & $3.628,00$ & $3.590,00$ & $-1,0$ \\
\hline Editorial & & 50.816 & 48.930 & $-3,7$ & $4.468,00$ & $2.332,00$ & -3 \\
\hline Audiovisual & & 50.572 & 46.169 & $-8,7$ & $2.784,00$ & $2.805,00$ & 0,8 \\
\hline Tecnologia & & 306.104 & 313.343 & 2,4 & $9.242,00$ & $8.831,00$ & $-4,5$ \\
\hline P\&D & & 166.300 & 164.346 & $-1,2$ & $11.765,00$ & $11.205,00$ & $-4,8$ \\
\hline TIC & & 112.942 & 120.601 & 6,8 & $6.351,00$ & $6.386,00$ & 0,6 \\
\hline Biotecnologia & & 26.862 & 28.396 & 5,7 & $5.784,00$ & $5.471,00$ & $-5,4$ \\
\hline
\end{tabular}

Os dados relevam ainda (Tabela 1) que apenas os setores ligados à cultura e à tecnologia não apresentaram redução da quantidade de trabalhadores, ainda que com decréscimo da média salarial. Isso pode ser explicado pelo fato de as atividades setoriais que compõem esse conjunto da indústria criativa serem intensivas em mão de obra. Conforme salientou Furtado (1978), os símbolos culturais e suas respectivas expressões não se reproduzem artificialmente, pois dependem da imaginação, da inventividade e da contextualidade humana. Ainda que a massificação da cultura e da arte em mercadorias reproduzíveis ocorra, não há como sua expansão viabilizar-se com redução do pessoal ocupado. Nesse caso, é importante destacar, no âmbito da cultura, muitos dos postos de trabalhos são informais, e, uma vez mensurados, reverberaria com uma distorção ainda maior.

Por meio do referencial teórico analisado, no que se refere aos autores evolucionários, com aspiração para a noção de cumulatividade do processo de trabalho elaborado por Karl Marx, também é possível explicar o crescimento do número de trabalhadores nos setores criativos de tecnologia. Porquanto, esses setores baseiam-se em rotinas e na especialização do trabalho para o desenvolvimento

Página 152 Caderno de Ciências Sociais Aplicadas, Vitória da Conquista/BA, vol. 16, n² 27, ano 16, p. 130-157, jan/jun 2019. 
de trajetórias tecnológicas, em que os conhecimentos científicos e tácitos são essenciais. Isso reforça e delineia a evidência teórica de que o processo de reprodução do capital na esfera industrial é sensível à criatividade científica, apontado por Celso Furtado. De todos os conjuntos setoriais, o de tecnologia foi o que apresentou maior redução da média salarial (4,5\%), apesar da magnitude salarial ser igualmente a maior registrada nesse mercado de trabalho.

Uma vez que a média salarial do conjunto setorial de tecnologia é superior ao registrado em todas as atividades econômicas criativas, haveria superexploração da força de trabalho? É possível afirmar que sim. Porquanto, nesses setores são contabilizados os registros ocupacionais e médias salarias de trabalhadores do setor público (centros de pesquisa e universidades). Se consideramos que o desenvolvimento de atividades de P\&D, por exemplo, não obedecem necessariamente ao expediente de trabalho, exigindo o emprego de tempo adicional em experimentos, estudos particulares extras a jornada de trabalho, anos de estudos superior à média (profissionais com mestrado e doutorado, por exemplo), constata-se que esses trabalhadores se submetem a jornadas exaustivas e com maior intensidade do trabalho, conforme Luce (2018). Ademais, tanto os trabalhadores da área cultural quanto os da área de tecnologia possuem sua força de trabalho esfoliada e, para o exercício da criatividade (cultural ou científica), necessitam recompor não apenas a força física, mas outros elementos determinantes para o valor da sua força de trabalho. Leitura de livros, realização de estudos, participação em eventos, tempo de lazer, realização de intercâmbios, entre outros fatores, são relevantes para a composição da criatividade. Isso porque, segundo Furtado (1978), a manifestação da criatividade é uma habilidade natural dos indivíduos, entretanto requer incentivos capazes de fornecer subsídios à imaginabilidade natural.

\section{Considerações finais}

Este artigo procurou discutir se a dinâmica da indústria criativa brasileira apresenta traços de superexploração na organização e natureza do trabalho alocado em setores criativos. Para isso, fundamentou-se na perspectiva de criatividade e subdesenvolvimento presentes em Furtado (1978) e Marini (1973). O ponto de partida foi a hipótese de que, nessa indústria, o capital se expropria do arcabouço cognitivo dos trabalhadores como mecanismo de geração de rendimentos adicionais. Procurou-se empregar um método hipotético-dedutivo, mas com abordagem dialética. O trabalho utilizou-se de dados do Mapeamento da Indústria Criativa, expondo-os ao argumento da superexploração.

Página 153 Caderno de Ciências Sociais Aplicadas, Vitória da Conquista/BA, vol. 16, n 27, ano 16, p. 130-157, jan/jun 2019. 
A discussão teórica e a aproximação da evidencia empírica indicam que o trabalho alocado na indústria criativa, como qualquer outra forma de trabalho, está sujeito à exploração. A remuneração salarial, compatível com a espoliação da força de trabalho, em que seja possível recompor o desgaste tanto, físico, quanto intelectual demonstra-se perfeitamente aderente à lógica de acumulação e reprodução do capital. Entretanto, em algumas atividades criativas, não apenas a força de trabalho física dos trabalhadores é expropriada pelos capitalistas, mas a sua capacidade intelectual, dada a sua criatividade artística ou cultural, também é desgastada, sem a devida recomposição. Isso porque, apesar de a criatividade ser um talento intrínseco a qualquer indivíduo, o estímulo ao seu exercício e a manifestação dependem das perfeitas condições de sobrevivência dos indivíduos. Além disso, o exercício da criatividade não obedece, necessariamente, a uma jornada de trabalho fixa, o que estende o exercício do trabalho.

Também se verifica neste artigo, conforme os dados do emprego criativo e a delimitação setorial da indústria criativa, que o capital, de alguma forma, expropria-se do arcabouço cultural intrínseco aos indivíduos como mecanismo de geração de rendimentos adicionais no âmbito produtivo, mediante a mercantilização das ideias e expressões culturais dos indivíduos, no campo da publicidade, moda, design e até mesmo da arquitetura e engenharia. São os elementos de originalidade, advindos da expressão criativa dos trabalhadores, que concedem preço adicional a essas mercadorias, sem, contudo, que a remuneração dos trabalhadores receba compensação.

Os resultados encontrados neste trabalho ainda são limitados, mas o seu objetivo de identificar evidências teóricas para superexploração da força de trabalho na indústria criativa demonstrou-se factível. É relevante incluir na discussão o aspecto da transnacionalização da indústria criativa, com a finalidade de expandir esse debate ao campo da dependência do Brasil em relação ao núcleo central da economia criativa, tanto tecnológica quanto artístico-cultural.

\section{Referências}

ADORNO, T. W; HORKHEIMER, M.. Dialética do esclarecimento: fragmentos filosóficos. Tradução de Guido Antonio de Almeida. Rio de Janeiro: Jorge Zahar, 1985.

ALBUQUERQUE, E. M. Inovação em Celso Furtado: criatividade humana e crítica ao capitalismo. In: D'AGUIAR, R. F. (Org.). Celso Furtado e a dimensão cultural do desenvolvimento. Rio de Janeiro: E-papers, 2013. p. 155-172.

Página 154 Caderno de Ciências Sociais Aplicadas, Vitória da Conquista/BA, vol. 16, n 27, ano 16, p. 130-157, jan/jun 2019. 
BAPTISTA, M. A. C. A abordagem neo-schumpeteriana: desdobramentos normativos e implicações para a política industrial. 1997. 145 f. Tese (Doutorado em Desenvolvimento Econômico) - Instituto de Economia, Universidade Estadual de Campinas, Campinas, 997.

BOCCARDELLI, P. Creative Industries. In.: AUDIER, M.; TEECE, D. J. The Palgrave Encyclopedia of Strategic Management. London: Palgrave Macmillan UK, 2016. p. 1-6.

BRANDÃO, C.. Território e desenvolvimento: as múltiplas escalas entre o local e o global. Campinas, Editora da Unicamp, 2007.

CARCANHOLO, M. (Im)precisões sobre a categoria superexploração da força de trabalho. In: Niemeyer Almeida Filho. (Org.). Desenvolvimento e Dependência: cátedra Ruy Mauro Marini. 1ed.Brasilia: IPEA, 2013, v. 1, p. 71-98.

CARCANHOLO, M. D. Dependência e Superexploração da Força de Trabalho no Desenvolvimento Periférico. Semináro Internacional REG GEN: Alternativas à Globalização. Rio de Janeiro: UNESCO, Organización de lasNaciones Unidas para laEducación, la Ciencia y la Cultura. Out./2005. Disponível em: http://www.trajetóriastecnológicasp://bibliotecavirtual.clacso.org.ar/ar/libros/reggen/pp06.pdf

CARCANHOLO, R. A. O trabalho produtivo na teoria marxista. In: Colóquio Internacional Marx Engels, V. Anais. Campinas: Unicamp, 2007. p. 1-10.

CASTELLS, M. A sociedade em rede. 3. ed. São Paulo: Paz e Terra, 2000

CAVAlCANTE, L. R. M. T. Produção teórica em economia regional: uma proposta de sistematização. Salvador: UFBA, 2001.

CROCCO, M. et al. Patentes e Sistemas Financeiros: um estudo exploratório para o Brasil *. Economia, v. 7, n. 12, p. 367-407, 2008.

CUCHE, D. A noção de cultura nas Ciências Sociais. Bauru: EDUSC, 2002.

DOSI, G. Sources, Procedures, and Microeconomic Effects of Innovation. Journal of economic literature, v. 26, n. 3, p. 1120-1171, 1988.

DOSI, G.; FAGIOLO, G.; ROVENTINI, A. Schumpeter meeting Keynes: A policy-friendly model of endogenous growth and business cycles. Journal of Economic Dynamics and Control, v. 34, n. 9, p. 1748-1767, 2010.

FIRJAN, FEDERAÇÃO DAS INDÚSTRIAS DO RIO DE JANEIRO. Mapeamento da Indústria Criativa no Brasil. Rio de Janeira: FIRJAN, 2016.

FLORIDA, R. The rise of the creative class. Nova York: Basic Books, 2002.

FURTADO, C.. Criatividade e dependência na civilização industrial. São Paulo: Paz e Terra, 1978.

Página 155 Caderno de Ciências Sociais Aplicadas, Vitória da Conquista/BA, vol. 16, n 27, ano 16, p. 130-157, jan/jun 2019. 
GOLGHER, A. B. As cidades e a classe criativa no Brasil: diferenças espaciais na distribuição de indivíduos qualificados nos municípios brasileiros. Revista Brasileira de Estudos Populacionais, São Paulo, v. 25, n. 1, p. 109-129, jan.-jun. 2008.

HARVEY, D. O enigma do capital. São Paulo: Boitempo, 2011.

JACOBS, J. Morte e vida das grandes cidades. São Paulo: Matins Fontes, 2001.

JEFFCUTRAJETÓRIAS TECNOLÓGICAS, P.; PRATRAJETÓRIAS TECNOLÓGICAS, A. C. Managing creativity in the cultural industries. Creativity and innovation management, v. 11, n. 4, p. 225-233, 2002.

KALECKI, M. (1954). Teoria da dinâmica econômica. Sao Paulo: Abril Cultural, 1983.

LUCE, M. S. Teoria marxista da dependência e categorias - uma visão histórica. São Paulo: Expressão Popular, 2018.

MACHADO, A. F. et al.. Urban amenities and the development of creative clusters: the case of Brazil, Current Urban Studies, New York, v. 1, n. 4, p. 92-101, dec. 2013.

MACULAN, A.-M. Capacitação tecnológica e inovação nas empresas brasileiras: balanço e perspectivas. Cadernos EBAPE.BR, p. 1-18, 2005.

MARINI, R. M. (2000 [1973]) Dialética da dependência. Petrópolis: Vozes, 2000.

MARX, K. O capital: crítica da economia política. 17. ed. Rio de Janeiro: Bertrand Brasil, 2001a. Livro I. [1867]

MARX, K. O capital: crítica da economia política. 17. ed. Rio de Janeiro: Bertrand Brasil, 2001b. Livro II. [1867]

NASCIMENTO, C. A. ; DILLENBURG, F. F. ; SOBRAL, F. M. . Exploração e Superexploração da Força de Trabalho em Marx e Marini.. In: ALMEIDA FILHO, N.. (Org.). Desenvolvimento e Dependência: cátedra Ruy Mauro Marini.. 1ed.Brasília: IPEA, 2013, v. 1, p. 99-123.

ROMERO, J. P. Mr. Keynes and the neo-Schumpeterians: Contributions to the analysis of the determinants of innovation from a post-Keynesian perspective. EconomiA, v. 15, n. 2, p. 189-205, 2014.

ROSENBERG, N. Perspectives on Technology. Cambridge: Cambridge University Press, Cap. 5, 1976.

SAWAYA, Rubens R.. Celso Furtado: criatividade e dependência na periferia. Estud. av., São Paulo , v. 22, n. 64, p. 327-334, Dec. 2008.

SCOTRAJETÓRIAS TECNOLÓGICAS, A. J. Cultural economy and the city creative field of the city. Geografiska Annaler: Series B, Human Geography, Londres, v. 92, n. 2, 2010. p. 115-130

Página 156 Caderno de Ciências Sociais Aplicadas, Vitória da Conquista/BA, vol. 16, n 27, ano 16, p. 130-157, jan/jun 2019. 


\section{- Cadernos de Clếnclas SOCIAIS APLICADAS}

SCOTRAJETÓRIAS TECNOLÓGICAS, Allen John. Flexible production systems and regional development: the rise of new industrial spaces in North America and Western Europe. International Journal of Urban and Regional Research, v. 12, n. 2, p. 171-186, 1988.

SCOTRAJETÓRIAS TECNOLÓGICAS, Allen John; STORPER, Michael. Production, work, territory: the geographical anatomy of industrial capitalism. Limited (Australia): Allen \& Unwin Pty., 1986.

SOUZA, T. C. A dinâmica e os efeitos de transbordamento da economia criativa no Brasil. 2015. 190 f. Dissertação (Mestrado em Economia Regional e Políticas Públicas) - Departamento de Ciências Econômicas, Universidade Estadual de Santa Cruz, Ilhéus, 2015.

SOUZA, T. C.; CACERES, Z. A. B. ; PIRES, M. M. Dinâmica, padrões espaciais e competitividade regional do emprego formal na economia criativa do Nordeste brasileiro. Revista Desenbahia, v. 12, p. 1-25, 2015.

STORPER, Michael; WALKER, Richard. The capitalist imperative: Territory, technology, and industrial growth. Blackwell, 1989.

SIMSKE, C. J. (1979). In Defense of the Hypothetical-Deductive Method. American Journal of Psychiatry, 136(2), $241-a-241$. 